UDC 546.719:54-386

O.A. Holichenko, N.I. Shtemenko, A.A. Ovcharenko, A.V. Shtemenko

\title{
INTERACTION OF DIRHENIUM(III) TRYPTOPHAN COMPLEX COMPOUND WITH DNA AND PROTEIN
}

\begin{abstract}
Ukrainian State University of Chemical Technology, Dnipro, Ukraine
We report about the interactions of dirhenium(III) compound cis$\left[\mathrm{Re}_{2}(\operatorname{Trp})_{2} \mathrm{Cl}_{4} \cdot\left(\mathrm{CH}_{3} \mathrm{CN}\right)_{2}\right] \mathrm{Cl}_{2}$ (I) with bovine serum protein (BSA) and guanine $(\mathrm{G} 4)$ quadruplexes DNA by UV-Vis titration. Addition of $\mathbf{I}$ to BSA led to the interaction between these compounds with binding constant 5.6 $10^{3} \mathrm{M}^{-1}$ and hyperchromism $(20.9 \%)$ of the main protein absorption band $(280 \mathrm{~nm})$. These results support our assumption about formation of the additional conjugated systems during the process of interaction with BSA. Stabilization of the quadruple bonded rhenium(III) complex compound was shown in the presence of BSA (the rate of destruction was reduced), that may be explained by interaction between amino acid residues of BSA and quadruple bond of dirhenium(III) complex compound. In addition, we have obtained data about strong hyperchromism (up to $100 \%$ ) and significant shift of the maximum of absorption (blue shift) towards UV (2$9 \mathrm{~nm}$ ) and visible $(22 \mathrm{~nm})$ regions in the spectra of mixtures G4s and $\mathbf{I}$, that, in our opinion, correlated with a conformational change in DNA and with formation of additional conjugated systems around quadruple bond of $\mathbf{I}$. In a whole, our work confirms the strong binding activity of a cluster dirhenium(III) compound towards G4 quadruplexes, that exceed the binding activity to proteins and witness to preferential interactions of I with G4 DNA in a living cell. These results may be used in DNA «silencing technology» and «antisense therapy».
\end{abstract}

Keywords: dirhenium(III) complex, bovine serum albumin, G4 DNA, tryptophan, binding constant, hyperchromism.

DOI: $10.32434 / 0321-4095-2021-137-4-35-40$

\section{Introduction}

Fundamental processes of gene regulation depend on the recognition of nucleic acid structure or base sequence by endogenous proteins or drugs. Interactions between nucleic acid and a drug can lead to the formation of complexes that act as architectural components of the cell and lead to up and down regulation of a specific gene [1]. It is known that serum proteins may perform transport function for metal-containing drugs by interaction with them; albumin as a serum protein being the most studied and convenient model for exploration of such interactions [2]. Quadruplex nucleic acids-helical four-stranded structures are formed from guaninerich nucleic acid sequences through Hoogsteen-type hydrogen bonding. They become important targets for small-molecule drugs, which can stabilize the quadruplex structures and thereby promoting selective down-regulation of gene expression and telomerase inhibition, and also activating DNA damage responses [3].

Tryptophan (Trp) is a biologically active essential amino acid, taking place in many biochemical processes [4]. As a fact, Trp residue is intercalated strongly between the base pairs of the 21-mer oligonucleotide duplex [1].

Dirhenium(III) complexes with an unique quadruple bond are especially promising candidates for clinical development due to their very low toxicity, anticancer and antioxidant activity [5,6]. Recently, we have synthesized and characterized a new compound, containing Trp ligands, bis-acetonitrilecis-tetrachlorodi- $\mu$-tryptophanatodirenium(III) chloride cis- $\left[\mathrm{Re}_{2}(\mathrm{Trp})_{2} \mathrm{Cl}_{4} \cdot\left(\mathrm{CH}_{3} \mathrm{CN}\right)_{2}\right] \mathrm{Cl}_{2}(\mathrm{I})$, as the dirhenium moieties [7] (Fig. 1).

Earlier, spectral investigations of the interaction between rhenium(III) clusters and albumins were conducted and information about possible 


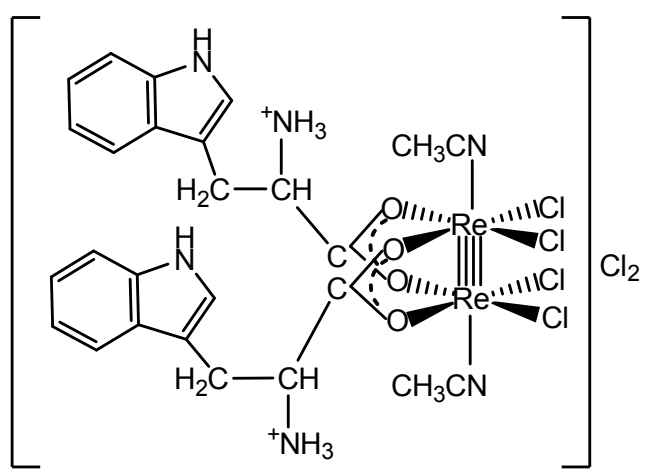

Fig. 1. Structure of bis-acetonitrile-cis-tetrachlorodi- $\mu$ tryptophanatodirenium(III) chloride cis- $\left[\operatorname{Re}_{2}(\operatorname{Trp})_{2} \mathrm{Cl}_{4} \cdot\left(\mathrm{CH}_{3} \mathrm{CN}\right)_{2}\right] \mathrm{Cl}_{2}(\mathrm{I})$

mechanisms of interactions between these molecules was obtained [8]. Taking into account all above, the purpose of the present study was to explore the interaction of I with albumin and two DNA G4 with the help of electronic absorption spectra (EAS).

\section{Materials and methods}

Bis-acetonitrile-cis-tetrachlorodi- $\mu$ tryptophanatodirenium(III) chloride cis$\left[\mathrm{Re}_{2}(\mathrm{Trp})_{2} \mathrm{Cl}_{4} \cdot\left(\mathrm{CH}_{3} \mathrm{CN}\right)_{2}\right] \mathrm{Cl}_{2}$ (I) was synthesized according to procedure described elsewhere [7] Bovine serum albumin (BSA) was purchased from Human (Germany). All oligonucleotides and cacodylate buffer components were purchased from Eurogentec. The sequences for the unlabeled oligonucleotides were c-kit1

\section{(5'-AGGGAGGGCGCTGGGAGGAGGG-3')} and HTelo22

\section{(5'-AGGGTTAGGGTTAGGGTTAGGG-3').}

The rhenium(III) complex compound was dissolved in milliQ water to give $2 \mathrm{mM}$ stock solution. All solutions were stored at $-20^{\circ} \mathrm{C}$. Before use, they were defrosted and diluted to yield the appropriate concentrations. The process of hydrolysis of I was investigated in physiological solution $(0.9 \% \mathrm{NaCl})$.

All spectral investigations were carried out on Cary 300 (Varian) spectrophotometer.

For titration of BSA with the complex compound, the following solutions were prepared: BSA (2 mg) was dissolved in $4 \mathrm{~mL}$ of saline $\left(\mathrm{C}_{\mathrm{m}}{ }^{0}=1.3 \cdot 10^{-5} \mathrm{~mol} \mathrm{~L}^{-1}\right)$; the complex compound ( $7 \mathrm{mg}$ ) was dissolved in $5 \mathrm{~mL}$ of saline $\left(\mathrm{C}_{\mathrm{m}}{ }^{0}=\right.$ $\left.=1.4 \cdot 10^{-3} \mathrm{~mol} \mathrm{~L}^{-1}\right)$. The following aliquots were then taken from this solution (in $\mu \mathrm{L}$ ): $5,5,10,10,10,10$, $50,100,100,100$, and 100. Further, they were added to a solution containing BSA and in a cuvette with saline, in relation to which the EAS was recorded to obtain differential spectral patterns.

The G4 DNA was dissolved in potassium or sodium cacodylate buffer $(10 \mathrm{mM} \mathrm{KCl} / 90 \mathrm{mM}$
$\mathrm{LiCl} / 10 \mathrm{mM}$ LiCac, pH 7.4). G4 DNA was dissolved in milliQ water to give $20 \mu \mathrm{M}$ stock solutions. The solutions were then diluted to $0.4 \mu \mathrm{M}$ by using the appropriate buffer and annealed at $95^{\circ} \mathrm{C}$ for $5 \mathrm{~min}$. Finally, they were allowed to slowly cool to room temperature overnight. The concentration of G4 DNA was checked by using their molar extinction coefficients. Ligands were diluted from stock solutions in the same buffer as the tested sequence to yield specific final concentrations.

The binding affinity of G4 DNA to Re(III) complexes was obtained from UV-Vis absorption titration from 230 to $900 \mathrm{~nm}$ at room temperature (constant G4 DNA concentration). 1-15 $\mu$ M of the complex were added to $1 \mu \mathrm{M}$ G4 DNA solution in a sample $1-\mathrm{cm}$ methacrylate cuvette and the mixture was incubated for $7 \mathrm{~min}$ prior to recording the absorption spectra. The titration was continued until only small changes in the absorption spectra were observed upon successive addition of rhenium complex compound.

Hyperchromism was calculated according the following formula:

$$
\% \text { Hyperchromism }=\left[\left(\mathrm{A}_{b}, \max _{\max }-\mathrm{A}_{\mathrm{b}, \min }\right) / \mathrm{A}_{\mathrm{b}, \max }\right] \cdot 100 \%,
$$

where $A_{b}$, max and $A_{b}$, min are the absorbances of bound complex with absorbance minimum and bound complex with absorbance maximum, respectively.

Binding data were analyzed according to the following equation [9] (at constant G4 DNA or BSA concentration) by plotting $\left(\mathrm{A}_{0} / \mathrm{A}-\mathrm{A}_{0}\right)$ vs. $1 / \mathrm{C}_{\mathrm{C}}$ dependences that give the binding constant $(\mathrm{K})$ as the ratio of the intercept to the slope:

$$
\frac{\mathrm{A}_{0}}{\mathrm{~A}-\mathrm{A}_{0}}=\frac{\varepsilon_{\mathrm{f}}}{\varepsilon_{\mathrm{b}}}+\frac{\varepsilon_{\mathrm{f}}}{\varepsilon_{\mathrm{b}} \mathrm{K}} \cdot \frac{1}{\mathrm{C}_{\mathrm{C}}},
$$

where $A_{0}$ and $A$ are the absorbances of G4 DNA or BSA in the absence and presence of the complex at $256 \mathrm{~nm}$ (for G4 DNA) and $280 \mathrm{~nm}$ (for BSA), respectively; $\varepsilon_{\mathrm{f}}$ and $\varepsilon_{\mathrm{b}}$ are the extinction coefficients of free and bounded G4 DNA or BSA, respectively; and $\mathrm{C}_{\mathrm{C}}$ is the concentration of the complex.

\section{Results and discussion}

Absorption of the dirhenium(III) clusters in the range of visible spectra $(500-900 \mathrm{~nm})$ resulted from $\delta \rightarrow \delta^{*}$ transition is a well-studied property of the quadruple bond [5,6]. Hydrolysis of the clusters with the subsequent destruction of the quadruple bond has been also studied [10,11]. As expected, the intensity of the band at $\lambda=610 \mathrm{~nm}$ was decreased with time in the visible spectra of the physiological solution of I (Fig. 2,a). 

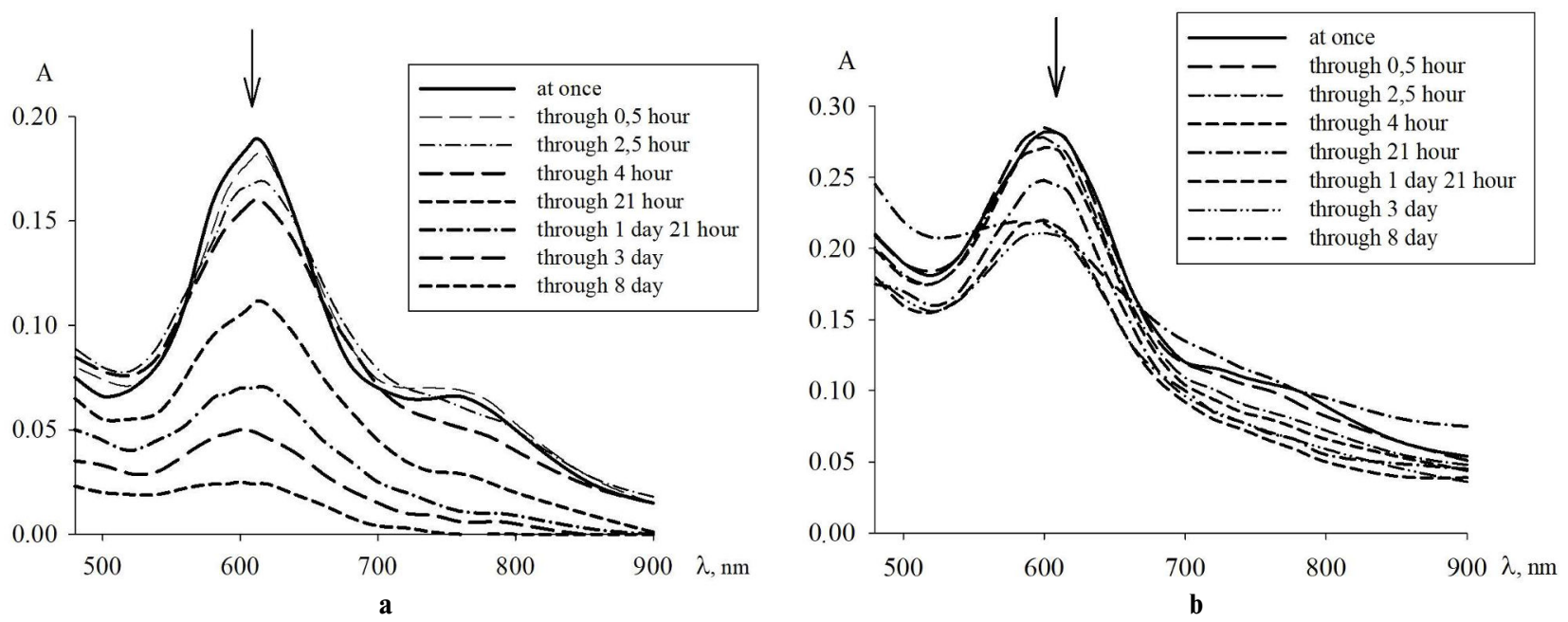

Fig. 2. Spectra of the physiological solution of I (a) and in the presence of BSA (b) in the area of absorption of the quadruple bond

The intensity of $\delta \rightarrow \delta^{*}$ transition is usually very low, but the addition of BSA increased the intensity of the band from 0.19 to 0.28 units of absorbance at once (Fig. 2,b). During 3 days after preparation, the cluster compounds I was destructed by approximately two times according to the extent of a decrease in the intensity of the characteristic band. In the presence of BSA, the rate of destruction was reduced and was decreased only by $28.6 \%$ through 3 days. Thus, it is a kind of stabilization of the quadruple bond, that may be explained by existence of interaction between amino acid residues of BSA and quadruple bond of $I$. The preferential type of binding may be formation of covalent bond between histidine and I with subsequent conjugation between quadruple bond and aromatic ring of the protein amino acid residues. If we compare these data with those obtained for interaction of the analogical compound of the cis-dicarboxylate type that has the main difference with I in ligands (isobutiric acid and tryptophan), we can clearly see that stabilization of the quadruple bond by BSA in I is much more effective. The intensity of the main peak in the experiments with isobutirate analogue was decreased from 0.44 to 0.36 units A (by $18.2 \%$ ) during 1 hour, and in experiments with the tryptophan compound it changed from 0.28 to 0.27 units of A (by $3.6 \%$ ). Thus, tryptophan moiety makes impact on the interaction with the protein, more likely through the inclusion of the aromatic ring of indole in the upper proposed conjugation.

The next step in the study on the interaction of BSA with I, was investigation of absorption of protein aromatic amino acid residues in the UV region of $280 \mathrm{~nm}$ under titration of the protein by I (Fig. 3).

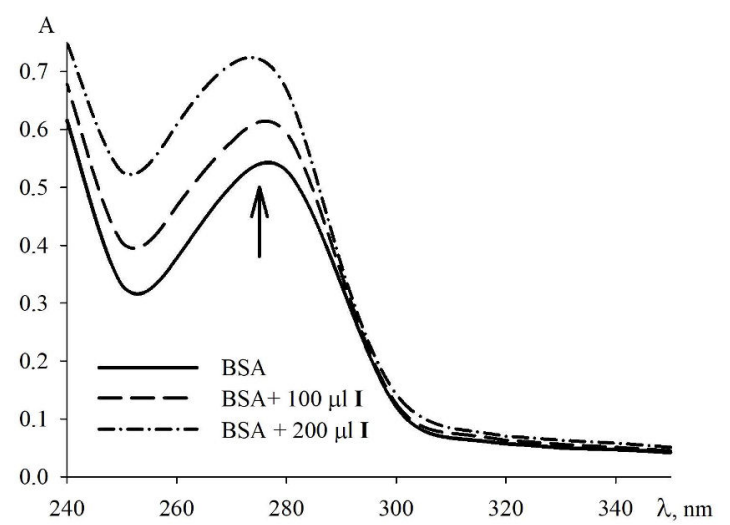

Fig. 3. UV-spectra of the titration of BSA $\left(\mathrm{C}_{\mathrm{M}}{ }^{0}=1.3 \cdot 10^{-5} \mathrm{~mol} \mathrm{~L}{ }^{-1}\right)$ by a solution of I

Here, we detected the hyperchromic effect that reached $20.9 \%$ and witnessed to the interaction of aromatic amino acids with I. These results support our assumption about formation of the additional conjugated systems during the process of interaction with BSA. In addition, such results may reflect the hydrophobic interaction of Trp with hydrophobic amino acids of the protein. The calculated constant of interaction is $5.6 \cdot 10^{3} \mathrm{M}^{-1}$. This value is lower than the constants of binding of different $\mathrm{Cu}$-complexes with BSA [12], the values of which reached $10^{4}-10^{5} \mathrm{M}^{-1}$.

The next part of our work was devoted to the investigation of interaction of two types of oligonucleotides with I with the use of the same approach. The results of the spectral titration are presented in the Table.

We have obtained data about essential hyperhromism and significant shift of the maximum of absorbtion to the low wave side (blue shift) in all 
Characteristics of the UV and visible spectroscopic titration of oligonucleotides

\begin{tabular}{c|c|c|c|c}
\hline Number of experiment & Compound & $\Delta \lambda_{\max }, \mathrm{nm}$ & Hyperchromism, \% & $\mathrm{K}, \mathrm{L} \mathrm{mol}^{-1}$ \\
\hline \multicolumn{7}{c}{ Parameters calculated from the UV spectra } \\
\hline 1 & c-kit1 (constant)+I & -2 & 90.20 & $7.02 \cdot 10^{3}$ \\
\hline 2 & HTelo22 (constant)+I & -9 & 103.58 & $1.31 \cdot 10^{5}$ \\
\hline \multicolumn{7}{c}{ Parameters calculated from the Vis spectra } \\
\hline 3 & c-kit1 (constant)+I & -22 & 70.09 & $1.28 \cdot 10^{4}$ \\
\hline 4 & HTelo22 (constant)+I & -22 & 89.23 & $5.95 \cdot 10^{4}$ \\
\hline
\end{tabular}

types of experiments that witnessed to the formation of new complexes. The binding constants for c-kit1 and for HTelo22 were lower than those for intercalating compounds $\left(10^{6}-10^{7} \mathrm{M}^{-1}\right)$ [13]. The blue shifts (Table) are approximately the same for both nucleotides, except the experiment No. 3. These data were observed from the first additions of the complex I (at the molar ratio DNA:I=1:1) and may witness to the formation of new complexes nucleotide-I with covalently bond of dirhenium(III) fragment with guanine through the axial positions of I. We have showed previously such structure of complexes with both purine bases [14].

The hyperchromism was very large for both nucleotides and reached more than $100 \%$ that to our knowledge was not shown before for any DNAbinders. When we compare these results with the data for BSA hyperchromism shown upper, then we can clearly see that I is preferentially bound to DNA, not to proteins. Hyperchromism and some shifts of the main absorbing bands were earlier shown for the series of mono- and bimetallic complexes (with $\mathrm{Cu}(\mathrm{II}), \mathrm{Pt}(\mathrm{II})$ and $\mathrm{Zn}(\mathrm{II}))$ during $\mathrm{UV} /$ vis spectroscopic titrations of some quadruplexes [15]. However only small shifts $(4-6 \mathrm{~nm})$ in absorption bands above $300 \mathrm{~nm}$ (those corresponding to metalto-ligand charge-transfer or intraligand $\pi-\pi^{*}$ transitions) were considered as characteristic of $\pi-\pi^{*}$ interaction with DNA bases. Maximal hypochromism in this zone reached $38 \%$. In this work, it was also confirmed that bi-metallic complexes had higher affinity towards G-quadruplexes DNA as compared to their monometallic counterparts. Large values of shifts and hyperchromicity obtained in our work may be explained by existence of bimetallic dirhenium(III) core and aromatic rings in the structure of I.

Analyzing the proposed mechanisms of G4-metal compounds interactions [3], we consider that the binding mode of I with DNA is not exclusively a result of a combination of $\pi-\pi$ stacking interactions, an electrostatic and covalent interaction. Indication of more than one binding mode can be rationalized by the multiple targeting nature of the complex: via $\pi-\pi$ stacking interactions atop quadruplex DNA (with the metal-benzimidazole core) as well as through electrostatic or covalent interactions via axial positions to bases/phosphate backbone in the loops.

According to the current state of our knowledge, we cannot explain the difference between obtained data for c-kit 1 and HTelo22 oligonucleotides, as both of them showed intensive interaction with I. The HTelo22 sequence contains no free guanines besides those participating in the G4 fold [3], whereas ckit 1 features three non-stacked guanines. In a whole, absorption in this region is a well-studied property of the dirhenium(III) clusters [5,6]. The analysis of energy position and intensity of the most long-waved band in EAS of the solutions of the rhenium compounds allows assigning it to $\delta \rightarrow \delta^{*}$-electron transition. We have found that the addition of the quadruplex (ckit-1 or HTelo22) led to intensive increase in this region, which was the same for both nucleotides. This increase in the intensity can describe formation of the complexes with the of quadruple $\mathrm{Re}-\mathrm{Re}$ bond.

\section{Conclusions}

The investigation of binding activity of I with BSA and two G4s DNA by the method of UV-vis absorption titration was performed. In the course of the addition of I to BSA, we detected the hyperchromic effect that witnessed to the interaction of aromatic amino acids with I. In addition, we observed the hyperchromic effect during titration of both G4 oligonucleotides in the area of absorption of DNA and quadruple bond. These results witness to the formation of the additional conjugated systems during the process of interaction with biological molecules. We may also assume that this active absorption appeared due to aggregation of the nucleotide-I complex that was shown in some previous investigations of unwinding oligonucleotides. All these mechanisms require additional investigations, but strong binding activity of I towards G4 quadruplexes showed the possibility of modifications of DNA, that may be used in future in medicine. 


\section{Acknowledgements}

This work is partly funded by the Ministry of Education and Science of Ukraine (project no. 0120U101957). Authors would like to thank the University of Valencia for the Atraccio al Talent grant for Professors Nataliia Shtemenko and Alexander Shtemenko.

\section{REFERENCES}

1. Jain A.A., Rajeswari M.R. Binding studies on peptideoligonucleotide complex: intercalation of tryptophan in GC-rich region of c-myc gene // Biochim. Biophys. Acta. - 2003. Vol.1622. - P.73-81.

2. Interaction of anticancer drugs with human and bovine serum albumin / Sulkowska A., Rownicka J., Bojko B., Sulkowski W. // J. Mol. Struct. - 2003. - Vol.651-653. - P.133-140.

3. Neidle S. Quadruplex nucleic acids as targets for anticancer therapeutics // Nat. Rev. Chem. - 2017. - Vol.1. Art. No. 0041.

4. Tryptophan biochemistry: structural, nutritional, metabolic, and medical aspects in humans / Palego L., Betti L., Rossi A., Giannaccini G. // J. Amino Acids. - 2016. - Vol.2016. - Art. No. 8952520.

5. Shtemenko A.V., Shtemenko N.I. Rhenium-platinum antitumor systems // Ukr. Biochem. J. - 2017. - Vol.89. No. 2. - P.5-30.

6. Synthesis, X-ray structure, interactions with DNA, remarkable in vivo tumor growth suppression and nephroprotective activity of cis-tetrachloro-dipivalato dirhenium(III) / Shtemenko N.I., Chifotides H.T., Domasevitch K.V., Golichenko A.A., Babiy S.A., Li Z., et al. // J. Inorg. Biochem. - 2013. - Vol.129. - P.127-134.

7. Roman A.A., Golichenko A.A., Shtemenko A.V. Cluster compounds of rhenium(III) with tryptophan // Izvestiya Vysshikh Uchebnykh Zavedenii, Seriya Khimiya i Khimicheskaya Tekhnologiya. - 2015. - Vol.58. - No. 6. - P.17-20.

8. Interaction of serum albumins with cluster rhenium compounds of cis- and trans-configuration / Leus I.V., Klenina I.O., Zablotska K.A., Golichenko O.A., Shtemenko O.V., Shtemenko N.I. // Biopolym. Cell. - 2011. - Vol.27. - No. 6. - P.465-471.

9. DNA G-quadruplexes binding and antitumor activity of palladium aryl oxime ligand complexes encapsulated in either albumin or algal cellulose nanoparticles / Esfahani N.H., Salami F., Saberi Z., Karami K., Lighvan Z.M., Ramezani M. et al. // Colloids Surf. B Biointerfaces. - 2019. - Vol.176. - P.70-79.

10. Synthesis and stability of the dirhenium(III) cluster compounds with isoleucine, serine and proline in aqueous solutions / Husak Y.V., Ovcharenko A.A., Golichenko A.A., Shtemenko A.V. // Voprosy Khimii i Khimicheskoi Tekhnologii. - 2020. - Vol.6. - P.38-43.
11. Hydrolysis of the dirhenium(III) complex compound with $\beta$-alanine / Ovcharenko A.A., Velichko O.V., Golichenko A.A., Shtemenko A.V. // Voprosy Khimii i Khimicheskoi Tekhnologii. - 2020. - Vol.4. - P.115-120.

12. Copper(II) diclofenac complexes: synthesis, structural studies and interaction with albumins and calf-thymus DNA / Kumar S., Sharma R.P., Venugopalan P., Ferretti V., Perontsis S., Psomas G. // J. Inorg. Biochem. - 2018. - Vol.187. - P.97-108.

13. Platinum phenanthroimidazole complexes as g-quadruplex DNA selective binders / Kieltyka R., Fakhoury J., Moitessier N., Sleiman H. // Chem. Eur. J. - 2008. - Vol.14. P.1145-1154.

14. Synthesis and $\mathrm{X}$-ray crystal structure of the dirhenium complex $\mathrm{Re}_{2}\left(\mathrm{i}-\mathrm{C}_{3} \mathrm{H}_{7} \mathrm{CO}_{2}\right)_{4} \mathrm{Cl}_{2}$ and its interactions with the DNA purine nucleobases / Shtemenko A.V., Chifotides H.T., Yegorova D.E., Shtemenko N.I., Dunbar K.R. // J. Inorg. Biochem. - 2015. Vol.153. - P.114-120.

15. Syntheses of polypyridyl metal complexes and studies of their interaction with quadruplex DNA / Stafford V.S., Suntharalingam K., Shivalingam A., White A.J.P., Mann D.J., Vilar R. // Dalton Trans. - 2015. - Vol.44. - P.3686-3700.

Received 15.03.2021

\section{ВЗАЕМОДІЯ ТРИПТОФАНОВОЇ КОМПЛЕКСНОЇ СПОЛУКИ ДИРЕНІЮ(III) 3 ДНК ТА БІЛКАМИ}

\section{О.А. Голіченко, Н.І. Штеменко, А.О. Овчаренко, \\ О.В. Штеменко}

Ми повідомляємо про взаємодію комплексної сполуки диренію(III) цис-[ $\left.\operatorname{Re}_{2}(\operatorname{Trp})_{2} \mathrm{Cl}_{4} \cdot\left(\mathrm{CH}_{3} \mathrm{CN}\right)_{2}\right] \mathrm{Cl}_{2}$ (I) 3 бичачим сироватковим альбуміном (БСА) і гуаніновими (G4) квадруплексами за допомогою UV-Vis титрування. Додавання I до БСА приводило до їх взаємодії із константою зв'язування $5,6 \cdot 10^{3} \mathrm{M}^{-1}$ та гіперхромізмом $(20,9 \%)$ основної смуги поглинання білка (280 нм). Ці результати підтверджують наше припущення про утворення додаткових зв'язаних систем у процесі взаємодії з БСА. Продемонстровано, що присутність БСА приводить до стабілізації комплексної сполуки ренію(III) з четверним зв'язком метал-метал (швидкість гідролізу при цьому знижується, що може бути пояснено взаємодією між амінокислотними залишками БСА і четверним зв'язком комплексної сполуки диренію(III)). Також отримані дані свідчать про сильний гіперхромізм (до 100\%) і значний зсув максимуму поглинання (синій зсув) в УФ (2-9 нм) та видимій (22 нм) ділянках спектрів для сумішей G4 i I, що, на наш погляд, корелює з конформаційною зміною ДНК і утворенням додаткових кон'югаційних систем навколо четверного зв'язку I. У цілому наша робота підтверджує сильну зв'язуючу активність кластерної сполуки диренію(III) по відношенню до G4-квадруплексів, яка перевищує активність зв'язування з білками, і свідчить про переважну взаємодію I з ДНК G4 у живій клітині. Ці результати можуть бути використані у «технології мовчання» ДНК та «антисенсотерапії.

Ключові слова: комплекс диренію(III), бичачий сироватковий альбумін, ДНK G4, триптофан, константи зв'язування, гіперхромізм. 


\section{INTERACTION OF DIRHENIUM(III) TRYPTOPHAN COMPLEX COMPOUND WITH DNA AND PROTEIN}

\author{
O.A. Holichenko ", N.I. Shtemenko, A.A. Ovcharenko, \\ A.V. Shtemenko
}

\section{Ukrainian State University of Chemical Technology, Dnipro, Ukraine \\ * e-mail: golichenko_alex@ukr.net}

We report about the interactions of dirhenium(III) compound cis- $\left[\mathrm{Re}_{2}(\operatorname{Trp})_{2} \mathrm{Cl}_{4} \cdot\left(\mathrm{CH}_{3} \mathrm{CN}\right)_{2}\right] \mathrm{Cl}_{2}(\mathrm{I})$ with bovine serum protein (BSA) and guanine (G4) quadruplexes DNA by UV-Vis titration. Addition of I to BSA led to the interaction between these compounds with binding constant $5.6 \cdot 10^{3} \mathrm{M}^{-1}$ and hyperchromism $(20.9 \%)$ of the main protein absorption band $(280 \mathrm{~nm})$. These results support our assumption about formation of the additional conjugated systems during the process of interaction with BSA. Stabilization of the quadruple bonded rhenium(III) complex compound was shown in the presence of BSA (the rate of destruction was reduced), that may be explained by interaction between amino acid residues of BSA and quadruple bond of dirhenium(III) complex compound. In addition, we have obtained data about strong hyperchromism (up to 100\%) and significant shift of the maximum of absorption (blue shift) towards UV (2-9 $\mathrm{nm})$ and visible $(22 \mathrm{~nm})$ regions in the spectra of mixtures $\mathrm{G} 4 \mathrm{~s}$ and $\mathbf{I}$, that, in our opinion, correlated with a conformational change in DNA and with formation of additional conjugated systems around quadruple bond of I. In a whole, our work confirms the strong binding activity of a cluster dirhenium(III) compound towards G4 quadruplexes, that exceed the binding activity to proteins and witness to preferential interactions of $\mathbf{I}$ with $\mathrm{G} 4$ DNA in a living cell. These results may be used in DNA «silencing technology» and «antisense therapy».

Keywords: dirhenium(III) complex; bovine serum albumin; G4 DNA; tryptophan; binding constant; hyperchromism.

\section{REFERENCES}

1. Jain AA, Rajeswari MR. Binding studies on peptideoligonucleotide complex: intercalation of tryptophan in GC-rich region of c-myc gene. Biochim Biophys Acta. 2003; 1622: 73-81. doi: 10.1016/S0304-4165(03)00119-3.

2. Sulkowska A, Rownicka J, Bojko B, Sulkowski W. Interaction of anticancer drugs with human and bovine serum albumin. J Mol Struct. 2003; 651-653: 133-140. doi: 10.1016/S0022-2860(02)00642-7.

3. Neidle S. Quadruplex nucleic acids as targets for anticancer therapeutics. Nat Rev Chem. 2017; 1: 0041. doi: 10.1038/s41570-017-0041.

4. Palego L, Betti L, Rossi A, Giannaccini G. Tryptophan biochemistry: structural, nutritional, metabolic, and medical aspects in humans. J Amino Acids. 2016; 2016: 8952520. doi: $10.1155 / 2016 / 8952520$.

5. Shtemenko AV, Shtemenko NI. Rhenium-platinum antitumor systems. Ukr Biochem J. 2017; 89(2): 5-30. doi: 10.15407/ubj89.02.005.
6. Shtemenko NI, Chifotides HT, Domasevitch KV, Golichenko AA, Babiy SA, Li Z, et al. Synthesis, X-ray structure, interactions with DNA, remarkable in vivo tumor growth suppression and nephroprotective activity of cis-tetrachlorodipivalato dirhenium(III). J Inorg Biochem. 2013; 129: 127-134. doi: 10.1016/j.jinorgbio.2013.09.001.

7. Roman AA, Golichenko AA, Shtemenko AV. Cluster compounds of rhenium(III) with tryptophan. Izv Vyssh Uchebn Zaved Khim Khim Tekhnol. 2015; 58(6): 17-20.

8. Leus IV, Klenina IO, Zablotska KA, Golichenko OA, Shtemenko OV, Shtemenko NI. Interaction of serum albumins with cluster rhenium compounds of cis- and trans-configuration. Biopolym Cell. 2011; 27(6): 465-471. doi: 10.7124/bc.000119.

9. Esfahani NH, Salami F, Saberi Z, Karami K, Lighvan ZM, Ramezani M, et al. DNA G-quadruplexes binding and antitumor activity of palladium aryl oxime ligand complexes encapsulated in either albumin or algal cellulose nanoparticles. Colloids Surf $B$ Biointerfaces. 2019; 176: 70-79.

doi: 10.1016/j.colsurfb.2018.12.050.

10. Husak YV, Ovcharenko AA, Golichenko AA, Shtemenko AV. Synthesis and stability of the dirhenium(III) cluster compounds with isoleucine, serine and proline in aqueous solutions. Voprosy Khimii i Khimicheskoi Tekhnologii. 2020; (6): 38-43. doi: 10.32434/0321-4095-2020-133-6-38-43.

11. Ovcharenko AA, Velichko OV, Golichenko AA, Shtemenko AV. Hydrolysis of the dirhenium(III) complex compound with $\beta$-alanine. Voprosy Khimii i Khimicheskoi Tekhnologii. 2020; (4): 115-120.

doi: 10.32434/0321-4095-2020-131-4-115-120.

12. Kumar S, Sharma RP, Venugopalan P, Ferretti V, Perontsis S, Psomas G. Copper(II) diclofenac complexes: synthesis, structural studies and interaction with albumins and calf-thymus DNA. J Inorg Biochem. 2018; 187: 97-108. doi: 10.1016/j.jinorgbio.2018.07.009.

13. Kieltyka R, Fakhoury J, Moitessier N, Sleiman H. Platinum phenanthroimidazole complexes as g-quadruplex DNA selective binders. Chem Eur J. 2008; 14: 1145-1154. doi: 10.1002/chem.200700783.

14. Shtemenko AV, Chifotides HT, Yegorova DE, Shtemenko NI, Dunbar KR. Synthesis and X-ray crystal structure of the dirhenium complex $\mathrm{Re}_{2}\left(\mathrm{i}-\mathrm{C}_{3} \mathrm{H}_{7} \mathrm{CO}_{2}\right)_{4} \mathrm{Cl}_{2}$ and its interactions with the DNA purine nucleobases. $J$ Inorg Biochem. 2015; 153: 114-120. doi: 10.1016/j.jinorgbio.2015.06.012.

15. Stafford VS, Suntharalingam K, Shivalingam A, White AJP, Mann DJ, Vilar R. Syntheses of polypyridyl metal complexes and studies of their interaction with quadruplex DNA. Dalton Trans. 2015; 44: 3686-3700. doi: 10.1039/C4DT02910K. 